\title{
The Importance of Trust In Counselors to The Effectiveness of Counseling Service at School
}

\author{
Suparman \\ Pelita Harapan University, Tangerang, Indonesia
}

\begin{abstract}
The purpose of this research is to know the importance of trust in counselors towards the effectiveness of counseling service at schools. This research uses a descriptive qualitative method, that is, to describe facts systematically and thoroughly. This will be conducted by collecting data and information to be arranged, explained, and analyzed. The trust shows that counselors can accept themselves and other people which can be seen through the healthy interpersonal communication that is built between counselors and counselees. This communication therefore is free from the needs of acceptance and the attitude of judging as the counselors have already first accepted themselves and other people. Counselors who have trust are the counselors who can be trusted by counselees. This happens because behind the trust there is a responsive attitude towards counselees or empathetic learning. This therefore leads to effective counseling process.
\end{abstract}

\section{INTRODUCTION}

Education in Indonesia not only focuses on the cognitive aspect, but also the development of the students as a unique person and completely. This is in accordance with Act of the Republic of Indonesia Number 20, Year 2003 on National Education System, which mentions education as a conscious and planned effort to create an atmosphere of learning and learning process so that learners are actively developing their potential to have religious spiritual strength, self-control, personality, noble moral intelligence, and skills needed himself, society, nation and state. The law also mentions, the function of education is to develop the ability and form the character and civilization of dignified nation in order to educate the nation's life, aims to the development of potential learners in order to become a human being who believes and cautious to God Almighty, noble, healthy, knowledgeable, capable, creative, independent and a democratic and responsible citizen. Clearly education not only instills knowledge, but also character.
Recognizing the importance of character development, the government then issued Presidential Regulation No. 87 of 2017 on Strengthening Character Education, where strengthening character education is a shared responsibility of family, educational unit, and society. It is in this context that counseling and guidance services are needed in schools. Surya Darma (2008) argues that every educational unit should provide services that can facilitate the personal development of students optimally and this can be achieved through guidance and counseling.

The key to the success of counseling and counseling services lies with the counselor. The process of guidance counseling in schools cannot be implemented mechanically, but involves a mutual relationship between counselor and counselee. Yeo (2009, p. 58) found that many counselors failed to handle counselees for not being able to touch themselves. This can lead to countertransference, the attitude of the counselor who responds emotionally to the counselee. Susabda (2014, p. 8) also 
found that the failure of counseling and counseling services because of the counselor's own factors, i.e. counselors who tend to quickly advise, judgmental, lack of self-disclosure to give insight to the counselee. This causes the counselor cannot see the problem clien objectively and less able to generate self-awareness in the counselee. The failure of the counselor also creates a misperception in the learner for the function of counseling and guidance services at the school, for example the school counselor is a "school policeman" charged with raiding, arresting, interrogating and taking steps against troubled children. These problems are on the one hand because the provision of guidance and counseling services tends to be clinical-therapeutic or curative approaches (Sudrajat, 1989), on the other hand because counselors are poorly trained and poorly understand their role as school counselors (Darma, 2008). As a result, counseling and guidance services in schools are ineffective, so it cannot support the achievement of educational goals.

Based on these studies, a concrete action is needed to improve the quality of school counseling services, so that counseling and guidance services at schools can take place effectively. One of the aspects raised in this paper is trust in the counselor. This study aims to determine how the importance of trust in the counselor to the effectiveness of counseling services. The discussion will use qualitative descriptive method to answer the question. Based on literature review it is found that trust plays a very important role in the counseling process (Hill, Helm \& Spiegel 1988, 1993, 1997). The existence of a trust indicates that the counselor can accept himself and others, so that he is able to establish healthy interpersonal communication. Communication is not accompanied by the need for acceptance or judgment attitude of others. Counselors who have trusts are counselors who can be trusted by the counselee. This happens because the credible attitude is contained responsive attitude to the counselee, which is sensitivity in the empathic listening. This is what causes the counseling process to run effectively.

\section{RESEARCH METHODS}

This research design using qualitative descriptive method. This method is still part of qualitative research, i.e. the way used to analyze, describe and describe phenomena or facts found in the field. This is as stated by Suyanto and Sutinah (2006), that descriptive research is intended to collect information in an actual and detailed way, identify problems, make comparisons or evaluations, and determine what others do in the face of similar problems and learn from their experiences to determine future plans and decisions. So research by this method does not seek and explain the relationship between two different variables and not test the hypothesis or make predictions, but rather re-describe the situation and events found in the field. The subjects of the study were 9th grade students at SMP Mentari in Tangerang. A method of data collection is done through observation and direct interview at school. Data analysis uses a literature review relating to counseling theory and practice of counseling, personality psychology, and developmental psychology.

\section{RESULTS AND DISCUSSION}

\section{School Counseling Services}

What is counseling services? Shertzer and Stone (1971, p. 40) argue that counseling services are "... the process of helping an individual to understand himself and his world." Sunaryo (1998, p. 3) mentions counseling services as a process of helping individuals to achieve development optimal. While Natawidjaja (1987, p. 37), interpreting guidance as a process of providing assistance to individuals conducted continuously, so 
that the individual can understand himself so that he can direct himself and can act fairly according to the demands and circumstances of the school environment, society and life in general. So counseling guidance service is a counseling effort done by a counselor to the counselee / learners in order to grow and develop optimally and able to overcome the problems faced.

Counseling guidance services in schools is an effort to help learners develop personal life, social life, learning activities, and career planning and development. Counseling guidance services facilitate the development of individual, group and / or classical learners according to their needs, potential, talents, interests, developments, conditions, and opportunities. This service also helps overcome the weaknesses, obstacles, and problems faced by learners. This service is not a classroom teaching activity but a counseling service conducted by a counselor (ABKIN, 2007). Thus counseling services have a very important role in the education process.

The practice of counseling services at SMP Mentari has followed the established program. The types of services provided to students include orientation, information, placement and channeling services, learning, individual counseling, group guidance, and group counseling. The areas of guidance provided include: personal, social, learning, and career guidance. The timing of counseling and counseling services is conducted during school hours and outside school hours. Based on these data it can be concluded that the program of guidance and counseling services at SMP Mentari has been in accordance with generally accepted procedures.

Based on direct interviews on some 9th grade students, randomly found reality, that they generally have poor perceptions of school counselor. They assume that school counselors are like the police in charge of supervising, raiding, arresting, and bringing to justice for children who skip school, fighting, often remedial (stupid), opposing teachers, late paying tuition fees, and so on. This, on the one hand, makes them fearful of being summoned by school counselor and on the other hand raises a feeling of reluctance to seek the help of school counselor even if they need their help. This reality shows that there is still no sense of security in the learners to follow the guidance and counseling services. Following up on this issue the counselor needs to update the approach that can bring the trust in the learner.

The importance of trust in counselors in counseling and guidance services

The key to counseling guidance lies with the counselor. The counselor must be an adult who has finished with himself. Before becoming a counselor, a person needs to undergo a personal counseling process so that he is able to come into contact with himself, aware of his values and beliefs, and be open to face his own problems. This not only minimizes the constraints of the counseling relationship, it also helps to get in touch with her own feelings and deal with counselee problems without getting too emotionally involved (Yeo, 1994).

Based on interview data indicate that in addition to tend to quickly advise, judgmental, and lacks of empathy, counselors at Mentari schools are also less daring self-disclosure to provide insight to the counselee. This causes the counselor cannot see the problem counselee objectively and less able to generate self-awareness in the counselee. Hill, Helm, \& Spiegel (1988, 1993, and 1997) in his study found that selfdisclosure counselors have a positive effect in the counseling process. The study also found that clients provide the highest ratings of helpfulness and exhibited the highest levels in response to counselor self-disclosure rather than other verbal responses. Knox et al. (1997) 
found that self-disclosure will lead to insight, making counselors more real as human beings, and making clients feel normal and reassured. This demonstrates the benefits of self-disclosure of counselors to assist counselees in the counseling process. So on the one hand, the counselor should be able to selfdisclosure so that counseling guidance services can run effectively; but on the other side in order to self-disclosure the counselor desperately needs a trust to help him enter a healthy interpersonal relationship. Counselors who develop less trust will have difficulty in counseling process, because they will tend to be judgmental, tend to be so suspicious that they cannot help the counselee see the problem objectively, lack of empathy, and difficulty in healthy interpersonal relationships.

Trust is the key to the effectiveness of the counseling process, since trust is a key component in building healthy relationships. Trust is defined as relying on people's behavior to achieve desired goals, whose accomplishments are uncertain and in risky situations (Griffin, 1967, pp. 224-34). Jalaludin explains this definition by dividing it into three beliefs: (1) there is a risky situation. When people trust someone, he or she will be ready to take risks. If there is no risk, then 'believe' is not necessary; (2) people who trust in others are aware that their consequences depend on the behavior of others; (3) the believer believes that the behavior of others will be good for him. So trust is the attitude of putting confidence in others that he will do something good against him in certain situations and conditions with all the risk that is ready to bear.

Trust is formed through one's life experiences during infancy and acceptance from the environment. A baby will grow well if his parents are responsive by feeding and caring well but not over-indulged or over-protected. Abandonment or violence against infants will undermine trust and the baby will develop a sense of mistrust. Babies who grow up with trust will be able to have hope and confidence that everything will be fine (Chapman, 2006). Similarly, responsive parents will build secure attachments, so children will feel safe and will learn to trust in their environment. Children will see examples of how their parents relate to their environment. If the parents show anxiety and full suspicion, then the child cannot develop a trust within himself. Furthermore, trust will grow in healthy relationships filled with acceptance, otherwise if in relation there are experiences of traumatic and full of rejection, it will develop a suspicious attitude and always wake up the more damaging one's relationship. Acceptance attitude is the attitude of individual acceptance of others without giving a negative assessment. This word also contains the meaning of 'respect', 'prizing', and 'non-possessive warmth' (Atkinson, 1995). A baby accepted by the environment will more easily accept himself and accept the existence of others. So counselors who are raised in responsive and full-admission families will more easily develop trust to clients and can speed up the counseling process. While counselors who grew up in families those are unresponsive and rejected, it is difficult to establish trusts that can hamper the counseling process.

\section{CONCLUSIONS}

Based on the above discussion can be concluded that the trust plays a very important role in conducting school guidance and counseling services. The existence of a trust indicates that the counselor can accept himself and others, so that he is able to establish healthy interpersonal communication. Communication is not accompanied by the need for acceptance or judgment attitude of others. Counselors who have trusts are counselors who can be trusted by the counselee. This happens because the credible attitude is contained responsive attitude to the counselee, which is sensitivity in the empathic listening. This 
is what causes the counseling process to run effectively.

The advice that can be given to a counselor is to go through a personal counseling process so that he is able to come into contact with himself, aware of his values and beliefs, and be open to deal with his own problems. This will foster a sense of trust in the counselor. In addition, counselors need adequate education and training on professional counseling before engaging in practical counseling practices.

\section{REFERENCES}

Akhmad Sudrajat 1989, Bimbingan dan Konseling di Sekolah, Diakses 20 September 2017, www.academia.edu/ download/41380793/bimbingan-dankonseling-di-sekolah.doc

Asosiasi Bimbingan dan Konseling Indonesia 2007, Penataan Pendidikan Profesional Konselor, Naskah Akademi ABKIN.

Atkinson, David J 1995, New Dictionary of Christian Ethic and Pastoral Theology, Inter Varsity Press, Leicester, England.

Chapman, Alan 2006, "Erikson's Psychosocial Development Theory", Diakses 9 Agustus 2017, http://www//businessballs.com/erik_eri kson's_ psychosocial_ development theory.

Hill, Clara E, Kim, Bryan SK, \& Gelso, CJ 2003, "Counselor Self - Disclosure, East Asian American Client Adherence to Asian Cultural Values a Counseling Process", Journal of Counseling Psychology, vol. 50, no. 3, pp 324-2.

Holmes, John, G, Rempel, \& John, K 1989. 'Trust in Close Relationship', Close Relationshipp, ed. ClydeHendrick, Sage Publications, New Bury Park.

Kartadinata, S 1998, Bimbingan di Sekolah Dasar, Direktorat Jenderal Pendidikan Tinggi. Departemen Pendidikan dan Kebudayaan, Jakarta.
Natawidjaja, R 1987, Pendekatan-pendekatan dalam Penyuluhan Kelompok I, Diponegoro, Bandung.

Rakhmat, J 1992, Psikologi Komunikasi, PT Remaja Rosdakarya, Bandung.

Shertzer \& Stones 1980, Fundamentals of Counseling, Houghton Mifflin Company, Boston.

Darma, S 2008, Bimbingan dan Konseling di Sekolah, Direktorat Tenaga Kependidikan Direktorat Jenderal Peningkatan Mutu Pendidik dan Tenaga Kependidikan Departemen Pendidikan Nasional 2008, Jakarta.

Susabda, YB, 2014, Konseling Pastoral. BPK Gunung Mulia, Jakarta.

Suyanto, B \& Sutinah 2006, Metode penelitian sosial, PT Kencana Persada, Jakarta.

Yeo, A 1994, Konseling: Suatu Pendekatan Pemecahan Masalah, BPK Gunung Mulia, Jakarta. 